\title{
Identification of Penicillium verrucosum, Penicillium commune, and Penicillium crustosum Isolated from Chicken Eggs
}

\author{
Soňa Demjanová, Pavlina Jevinová (D), Monika Pipová *(D) and Ivana Regecová
}

Citation: Demjanová, S.; Jevinová, P.; Pipová, M.; Regecová, I. Identification of Penicillium verrucosum, Penicillium commune, and Penicillium crustosum Isolated from Chicken Eggs. Processes 2021, 9, 53. https://doi.org/10.3390/ pr9010053

Received: 18 November 2020 Accepted: 23 December 2020 Published: 29 December 2020

Publisher's Note: MDPI stays neutral with regard to jurisdictional claims in published maps and institutional affiliations.

Copyright: (C) 2020 by the authors. Licensee MDPI, Basel, Switzerland. This article is an open access article distributed under the terms and conditions of the Creative Commons Attribution (CC BY) license (https: / / creativecommons.org/ licenses/by/4.0/).
Department of Food Hygiene, Technology and Safety, The University of Veterinary Medicine and Pharmacy in Košice, Komenského 73, 04181 Košice, Slovakia; sona.demjanova@student.uvlf.sk (S.D.); pavlina.jevinova@uvlf.sk (P.J.); ivana.regecova@uvlf.sk (I.R.)

* Correspondence: monika.pipova@uvlf.sk

Abstract: Penicillium species belong to main causative agents of food spoilage leading to significant economic losses and potential health risk for consumers. These fungi have been isolated from various food matrices, including table eggs. In this study, both conventional Polymerase Chain Reaction (PCR) and Polymerase Chain Reaction-Internal Transcribed Spacer-Restriction Fragment Length Polymorphism (PCR-ITS-RFLP) methods were used for species identification of Penicillium (P.) spp. isolated from the eggshells of moldy chicken eggs. Seven restriction endonucleases (Bsp1286I, XmaI, HaeIII, HinfI, MseI, SfcI, Hpy188I) were applied to create ribosomal restriction patterns of amplified ITS regions. To identify P. verrucosum, P. commune, and P. crustosum with the help of conventional PCR assay, species-specific primer pairs VERF/VERR, COMF/COMR, and CRUF/CRUR were designed on the base of 5.8 subunit-Internal Transcribed Spacer (5.8S-ITS) region. Altogether, 121 strains of microscopic filamentous fungi were isolated by traditional culture mycological examination. After morphological evaluation of both macroscopic and microscopic features, 96 strains were classified in Penicillium spp. Two molecular methods used have confirmed eight isolates as $P$. verrucosum, 42 isolates as P. commune, and 19 isolates as P. crustosum. Both PCR-ITS-RFLP and conventional PCR assays appear to be suitable alternatives for rapid identification of the above mentioned Penicillium species.

Keywords: mold; egg; Penicillium; colony morphology; Ehrlich reaction; creatine; restriction enzyme; PCR; PCR-ITS-RFLP

\section{Introduction}

Penicillium spp. is one of the most common microscopic filamentous fungi in foodprocessing industry with more than 200 species known so far [1]. As mesophiles, Penicillium species grow best at temperatures between $5^{\circ} \mathrm{C}$ and $37^{\circ} \mathrm{C}$, water activity from 0.78 to 0.88 and $\mathrm{pH}$ level from 3 to 4.5 . They occur in soil, on decomposing vegetation and compost, on dried food, spices, cereals, in fresh fruits and vegetables, as well as in the air and dust [2]. They can also grow on the building walls, especially when the humidity of building material is high [3]. Many Penicillium species have the ability to produce a wide range of metabolites, including antibiotics, antiviral agents, and mycotoxins [4].

Foods of animal origin, and in particular table eggs, are also susceptible to contamination by microscopic filamentous fungi. This contamination can be involved by a variety of sources, e.g., feces, litter, feed, but also from improper handling and storage [5]. In accordance with Commission Regulation No 589/2008 [6], fresh table eggs can be stored at temperatures above $+5{ }^{\circ} \mathrm{C}$ for 28 days after laying. Such conditions favor the development of molds on the eggshell and often lead to significant economic losses due to egg devaluation and subsequent condemnation. Currently, no information on the occurrence of individual Penicillium species in table eggs are available worldwide. Fungal species, including Penicillium (P.) crustosum and P. verrucosum, have already been identified among cheese contaminating mycoflora with reported optimum growth temperatures between $15^{\circ} \mathrm{C}$ and $25^{\circ} \mathrm{C}$ [7-9]. As temperatures close to $+15^{\circ} \mathrm{C}$ are preferably used in egg storage 
facilities, the presence of all the three Penicillium species could be predicted in table eggs during storage.

Monitoring and identification of microscopic filamentous fungi in food has gained increased attention of food producers, control authorities, and researchers around the world. Identification of Penicillium species is primarily based on morphological criteria, such as macroscopic and microscopic features [10,11]. However, this often leads to identification problems. Classical cultivation methods are time-consuming, labor-intensive, non-quantitative, and susceptible to contamination and inaccuracies in classification.

Rapid and reliable identification of microscopic filamentous fungi can contribute to better process management and control in the food sector as well as to a higher level of consumers' health protection. Therefore, molecular methods focused on genotypic characterization have proved their utility. In general, genomic deoxyribonucleic acid (DNA) analysis using the Polymerase Chain Reaction (PCR)-based methods is a fast, sensitive, and reliable possibility for differentiation of microorganisms [12]. In fungal diagnostics, sequence targets within the ribosomal DNA gene complex are proven in identifying different species of microscopic filamentous fungi. Internal Transcribed Spacer (ITS) sequences of ribosomal ribonucleic acid (rRNA) including the highly conserved 18S, 5.8S, 28S genes and internal transcribed spacer regions ITS1 and ITS show low intraspecific polymorphism and high interspecies variability [13]. Currently, the ITS region amplification and sequencing followed by comparison to sequences deposited in the GenBank is the preferred method worldwide. So far, many molecular techniques have been developed for studying population genetic diversity. Such methods as amplified fragment length polymorphism (AFLP), random amplified polymorphic DNA (RAPD), or mini/microsatellite DNA are used to detect polymorphisms at the genome level. The restriction fragment length polymorphism (RFLP) can be used to distinguish variations in the DNA sequences that may not be expressed at the protein level [14,15].

$P$. verrucosum, $P$. commune, and $P$. crustosum are frequently reported causes of spoilage in wide range of plant food and food materials [16-18]. Moreover, P. verrucosum is known for production of ochratoxin A [19] and citrinin [20], and P. crustosum is capable of producing penitrem A [21] and roquefortine $C$ [20]. Production of fumigaclavines A and B [22], penitrem A, roquefortine [23], and cyclopiazonic acid has already been reported for P. commune [20].

Morphological identification of the above species is time-consuming, challenging, and often inaccurate in the classification. The aim of this study was to design a rapid and effective identification method for Penicillium species isolated from table eggs. So far, conventional PCR assays have not been used to distinguish closely related species of P. verrucosum, P. commune, and P. crustosum. Therefore, three species-specific primer pairs were designed and introduced in this study. To verify the specificity and reliability of the newly designed PCR protocol, the results were confirmed by PCR-ITS-RFLP analysis.

\section{Materials and Methods}

\subsection{Mold Cultures}

The strains of microscopic filamentous fungi were isolated from the shell surfaces of 40 moldy chicken eggs from Slovak laying hen breeding according to the instructions of STN ISO 21527-1 [24] and STN ISO 21527-2 [25].

\subsection{Phenotypic Identification}

Mold isolates were tested phenotypically according to standardized procedures [11]. Isolated colonies of microscopic filamentous fungi considered to belong to different mold genera or species were inoculated on the surface of Yeast Extract Sucrose agar medium (YES), Czapek Yeast Autolysate agar medium (CYA) and Malt Extract Agar medium (MEA) (Hi-Media, Mumbia, India) and incubated for 7 days at $25^{\circ} \mathrm{C}$. Macroscopic evaluation was focused on the rate of colony growth, color, texture and corrugation, and the presence of exudate and pigment. Microscopic evaluation was performed on agar preparations 
stained with lacto phenol cotton blue under optical microscope. Micromorphological structures (stripes, metulae, phialides, and conidia) were measured and documented using the B-290TB optical microscope and Optika Vision Lite 2.13 analysis software (OPTIKA ${ }^{\circledR}$ Microscopes, Ponteranica, Italy).

All isolates classified in Penicillium spp. were identified according to the criteria of Frisvad and Samson [11]. Individual Penicillium strains grown on CYA were further tested for the production of cyclopiazonic acid and other alkaloids reacting with Ehrlich reagent. In this test, the violet or purple reaction was considered positive for cyclopiazonic acid production, while the yellow or pink reactions indicated the production of other alkaloids. Negative reaction was not manifested by any change in color. Ability of strains to metabolize creatine with concomitant acid production was determined by inoculation of Creatine Sucrose Agar medium (CREA; Hi-Media, Mumbia, India).

\subsection{DNA Isolation}

Total genomic DNA of the tested strains was isolated by a two-step procedure using zircon and glass beads, Proteinase K (Macherey-Nagel GmbH \& Co., Dueren, Germany), ultrasound waves and commercially available E.Z.N.A. ${ }^{\circledR}$ Fungal DNA Mini Kit (OMEGA Bio-tek, Inc., Norcross, GA, USA) according to Regecová et al. [26]. The purity and concentration of DNA was measured using the BioSpec spectrophotometer (SHIMADZU, Kjóto, Japan).

\subsection{Species-Specific Identification by PCR-ITS-RFLP Method}

The universal primers ITS1 5'-TCCGTAGGTGAACCTGCGG-3' (forward) and ITS4 $5^{\prime}$-TCCTCCGCTTATTGATATGC-3' (reverse) were used for amplification of the 5.8S-ITS region in tested isolates [27].

The amplification was performed in a volume of $20 \mu \mathrm{L}$ containing $4.0 \mu \mathrm{L}$ HOT Firepol ${ }^{\circledR}$ Blend Master Mix (Solis BioDyne, Tartu, Estonia), $0.5 \mu \mathrm{L}$ of each primer (concentration $10 \mathrm{pmol} / \mu \mathrm{L}$ ) and $1 \mathrm{ng}$ to $10 \mathrm{ng}$ of DNA in the thermal cycler TC-512 (Techne, Stadfforshire, UK). The PCR protocol used was as follows: initial cycling step at $95^{\circ} \mathrm{C}$ for $12 \mathrm{~min}$, DNA denaturation at $95^{\circ} \mathrm{C}$ for $20 \mathrm{~s}$, annealing at $53{ }^{\circ} \mathrm{C}$ for $60 \mathrm{~s}$, and elongation at $72{ }^{\circ} \mathrm{C}$ for $2 \mathrm{~min}$. The amplification was terminated by cooling to $6^{\circ} \mathrm{C}$.

The following reference strains were used as positive controls in this study: P. verrucosum ATCC $^{\circledR} 44407^{\mathrm{TM}}$ (American Type Culture Collection, Manassas, VA, USA), P. commune CCM F-327, and P. crustosum CCM 8322 (Czech Collection of Microorganisms, Brno, Czech Republic).

The PCR products were subsequently digested with restriction endonucleases Bsp1286I, XmaI, HaeIII, HinfI, MseI, SfcI, and Hpy188I (New England BioLabs ${ }^{\circledR}$ Inc., Ipswich, MA, USA) by modified procedure according to Diguţă et al. [28]. The length of individual fragments was evaluated using the GelAnalyzer 19.1. (Version 14.0.0.0; Oracle Corporation, Redwood City, CA, USA).

\subsection{Species-Specific Identification by Conventional PCR Method}

Fungal isolates were also identified by conventional PCR method. The primer design was based on ITS region and 5.8S rRNA sequences available in the GenBank-European molecular Biology Laboratory database (GenBank-EMBL).

The 5.8S-ITS rRNA sequences of $P$. verrucosum, $P$. crustosum, and P. commune reference strains were retrieved from available databases (GenBank and EMBL). The primers were designed with the help of Primer3 Input (Version 0.4.0; http:/ / bioinfo.ut.ee/primer3-0 $.4 .0 /$ ) and then synthesized commercially by Amplia s.r.o. (Bratislava, Slovakia). These primers were reported to amplify a conserved region of 99 bp of the 18S rRNA gene in all the eukaryotic species [29]. The amplification protocol was similar to that described for PCR-ITS-RFLP method, but the annealing ran at different temperatures depending on the type of primer used (Table 1 ). 
Table 1. Primers designed and used in this study.

\begin{tabular}{|c|c|c|c|c|}
\hline $\begin{array}{l}\text { Primer } \\
\text { Name }\end{array}$ & Primer Sequence $\left(5^{\prime}-3^{\prime}\right)$ & $\begin{array}{l}\text { Annealing } \\
\text { Temperature } \\
\left({ }^{\circ} \mathrm{C}\right)\end{array}$ & $\begin{array}{l}\text { Size of PCR } \\
\text { Product }\end{array}$ & $\begin{array}{c}\text { GenBank-EMBL } \\
\text { Accession } \\
\text { Number }\end{array}$ \\
\hline \multicolumn{5}{|c|}{ Penicillium verrucosum } \\
\hline $\begin{array}{l}\text { VERF } \\
\text { VERR }\end{array}$ & $\begin{array}{l}\text { TCGTAACAAGGTTTCCGTAGG } \\
\text { TTTCCTTCCGCCTTATTGAT }\end{array}$ & 59 & $607 \mathrm{bp}$ & DQ681351.1 \\
\hline $\begin{array}{l}\text { COMF } \\
\text { COMR }\end{array}$ & $\begin{array}{l}\text { enicillium commune } \\
\text { CCCGTGTTTATTTTACCTTG } \\
\text { CTGGATAAAATTTGGGTTGA }\end{array}$ & 51 & $464 \mathrm{bp}$ & GQ340555.1 \\
\hline $\begin{array}{l}\text { CRUF } \\
\text { CRUR }\end{array}$ & $\begin{array}{l}\text { enicillium } \text { crustosum } \\
\text { TCCCACCCGTGTTTATTTTA } \\
\text { TCCСTTTCAACAATTTCACG }\end{array}$ & 58 & 892 bp & HQ225711.1 \\
\hline
\end{tabular}

The reference strains used as positive controls in the conventional PCR protocol included P. verrucosum ATCC ${ }^{\circledR} 44407^{\mathrm{TM}}$ (American Type Culture Collection, Manassas, VA, USA), P. commune CCM F-327, P. crustosum CCM 8322, P. chrysogenum CCM F-362, P. brevicompactum CCM 8040, P. glabrum CCM F-310, and P. expansum CCM F-576 (Czech Collection of Microorganisms, Brno, Czech Republic).

\subsection{Detection of PCR Products}

The PCR products were size fractionated in agarose gels $(1.5 \%)$ with the GelRed ${ }^{\mathrm{TM}}$ Nucleic Acid gel stain (Biotium, Inc., Fremont, CA, USA). Amplicons were visualized by UV transillumination using the Mini Bis Pro ${ }^{\circledR}$ (DNR Bio-Imaging Systems Ltd., Neve Yamin, Izrael). The DNA Ladder of 50 bp (Sigma-Aldrich, Saint Louis, MO, USA) was used as molecular size marker for PCR-ITS-RFLP and the DNA Ladder of $100 \mathrm{bp}$ (Sigma-Aldrich, Saint Louis, MO, USA) was used for species-specific PCR identification.

The identity of PCR products with the selected primers was confirmed by a commercial company (GATC Biotech AG, Cologne, Germany). The DNA sequences obtained from fungal strains were searched for homology to those available at the GenBank-EMBL database using the Basic Local Alignment Search Tool (BLAST) program (NCBI, software package 3.40, Bethesda, MD, USA).

\section{Results}

\subsection{Phenotypic Identification}

Strains of microscopic filamentous fungi $(n=121)$ isolated from chicken eggshells were subjected to phenotypic identification. According to characteristic macroscopic and microscopic features, 96 isolates were identified as Penicillium spp. Confirmed isolates were further examined by both Ehrlich reaction and Creatine test. Based on the results obtained, 12 isolates were identified as P. verrucosum, 42 as P. commune, and 21 as P. crustosum (Table 2).

Strains of microscopic filamentous fungi classified as $P$. verrucosum shown a good growth on MEA, CYA, and YES media, with average colony diameters (25.25 \pm 8.84$)$ $\mathrm{mm}$ for MEA; $(25.42 \pm 8.56) \mathrm{mm}$ for CYA and $(22 \pm 10.41) \mathrm{mm}$ for YES agar after 7 day incubation at $25^{\circ} \mathrm{C}$. On both MEA and CYA, colonies were velutinous to floccose texture, green with a white edge hem and corrugation. Clear copious exudate droplets were present. Reverse colony color was light yellow-brown on MEA and cream yellow on CYA. Velutinous green colonies with a white edge hem and beige brown to terracotta reverse color were typical for $P$. verrucosum grown on YES medium. Conidiophores were terverticillate with rough walled-stripe, phialides were cylindrical tapering to a distinct collulum. Conidia were smooth-walled or rough-walled, globose to subglobose. Negative Ehrlich reaction was observed in nine isolates (Table 2, Figure 1). 
Table 2. Phenotypic features and morphological identification of three Penicillium species isolated from chicken eggs.

\begin{tabular}{|c|c|c|c|c|c|c|c|}
\hline \multirow{2}{*}{ Fungal Species } & \multirow{2}{*}{ Number of Isolates } & \multicolumn{3}{|c|}{ Colony Size (mm) } & \multirow{2}{*}{ Ehrlich Reaction } & \multicolumn{2}{|c|}{ Creatine Test } \\
\hline & & MEA & CYA & YES & & Growth & Acid Production \\
\hline $\begin{array}{l}\text { Penicillium } \\
\text { verrucosum }\end{array}$ & 12 & $13-37$ & $14-41$ & $11-41$ & $\begin{array}{c}\text { negative (9) } \\
\text { pink (2) } \\
\text { yellow (1) }\end{array}$ & $\begin{array}{l}\text { weak (7) } \\
\text { good (5) }\end{array}$ & $\begin{array}{l}-(8) \\
+(4)\end{array}$ \\
\hline $\begin{array}{l}\text { Penicillium } \\
\text { commune }\end{array}$ & 48 & $26-40$ & $23-41$ & $24-42$ & $\begin{array}{l}\text { negative (6) } \\
\text { purple (10) } \\
\text { violet (32) }\end{array}$ & $\begin{array}{l}\text { weak (9) } \\
\text { good (39) }\end{array}$ & $\begin{array}{c}+(11) \\
++(13) \\
+++(24)\end{array}$ \\
\hline $\begin{array}{l}\text { Penicillium } \\
\text { crustosum }\end{array}$ & 21 & $27-37$ & $28-39$ & $24-39$ & $\begin{array}{c}\text { negative (13) } \\
\text { yellow (8) }\end{array}$ & $\begin{array}{c}\text { weak (7) } \\
\text { good (14) }\end{array}$ & $\begin{array}{c}-(7) \\
++(14)\end{array}$ \\
\hline
\end{tabular}

MEA Malt Extract Agar; CYA Czapek Yeast Autolysate agar; YES Yeast Extract Sucrose agar; - none; + weak; ++ good; +++ strong; numbers in parentheses indicate the number of strains showing a particular reaction.
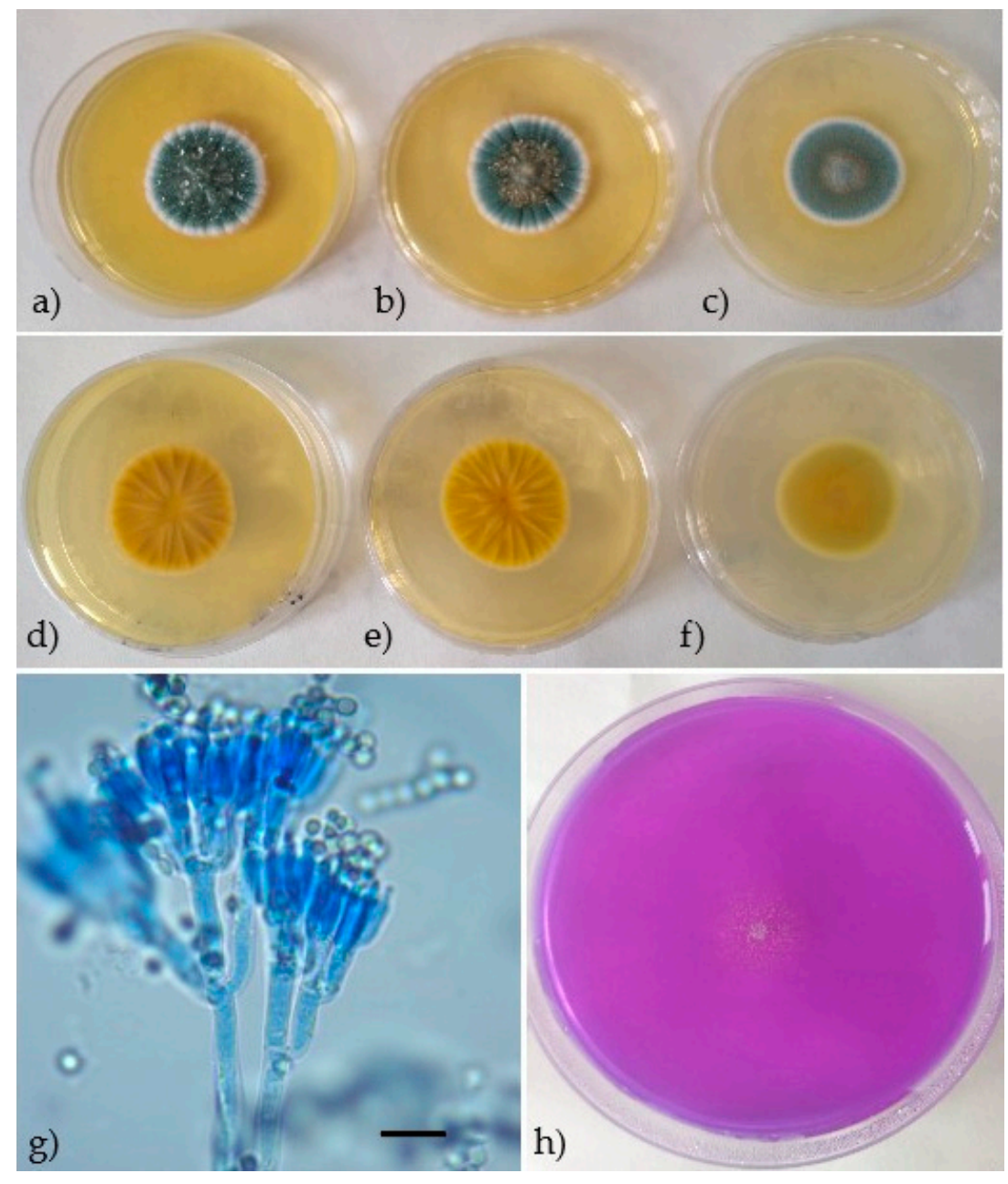

Figure 1. Penicillium verrucosum. Seven-day-old colonies on Malt Extract Agar (MEA) (a) obverse, (d) reverse, Czapek Yeast Autolysate agar (CYA) (b) obverse, (e) reverse, Yeast Extract Sucrose agar (YES) (c) obverse, (f) reverse, (h) Creatine Sucrose Agar (CREA)-no acid production, (g) conidiophores and conidia. Scale: black bar $=10 \mu \mathrm{m}$.

The growth of $P$. commune isolates on MEA, CYA, and YES media was very good with average colony diameters $(35.46 \pm 3.78) \mathrm{mm}$ for MEA, $(35.46 \pm 4.45) \mathrm{mm}$ for CYA and $(33.63 \pm 5.30) \mathrm{mm}$ for YES agar following incubation at $25^{\circ} \mathrm{C}$ for 7 days. Colonies on both MEA and CYA were floccose to fasciculate texture, blue green to green color with a white edge hem. Clear exudate droplets were often observed. Reverse colony color was beige to 
beige brown on MEA and cream yellow on CYA. Velutinous blue green colonies with a white edge hem, corrugation, and beige yellow reverse color were typical for $P$. commune grown on YES medium. Conidiophores were terverticillate with rough-walled stripe, phialides cylindrical tapering to a distinct collulum. Conidia were smooth-walled, globose to subglobose. The potential production of cyclopiazonic acid was manifested in 32 isolates as violet reaction and in another 10 isolates as purple reaction. In a half of P. commune isolates, strong acid production was also confirmed (Table 2, Figure 2).
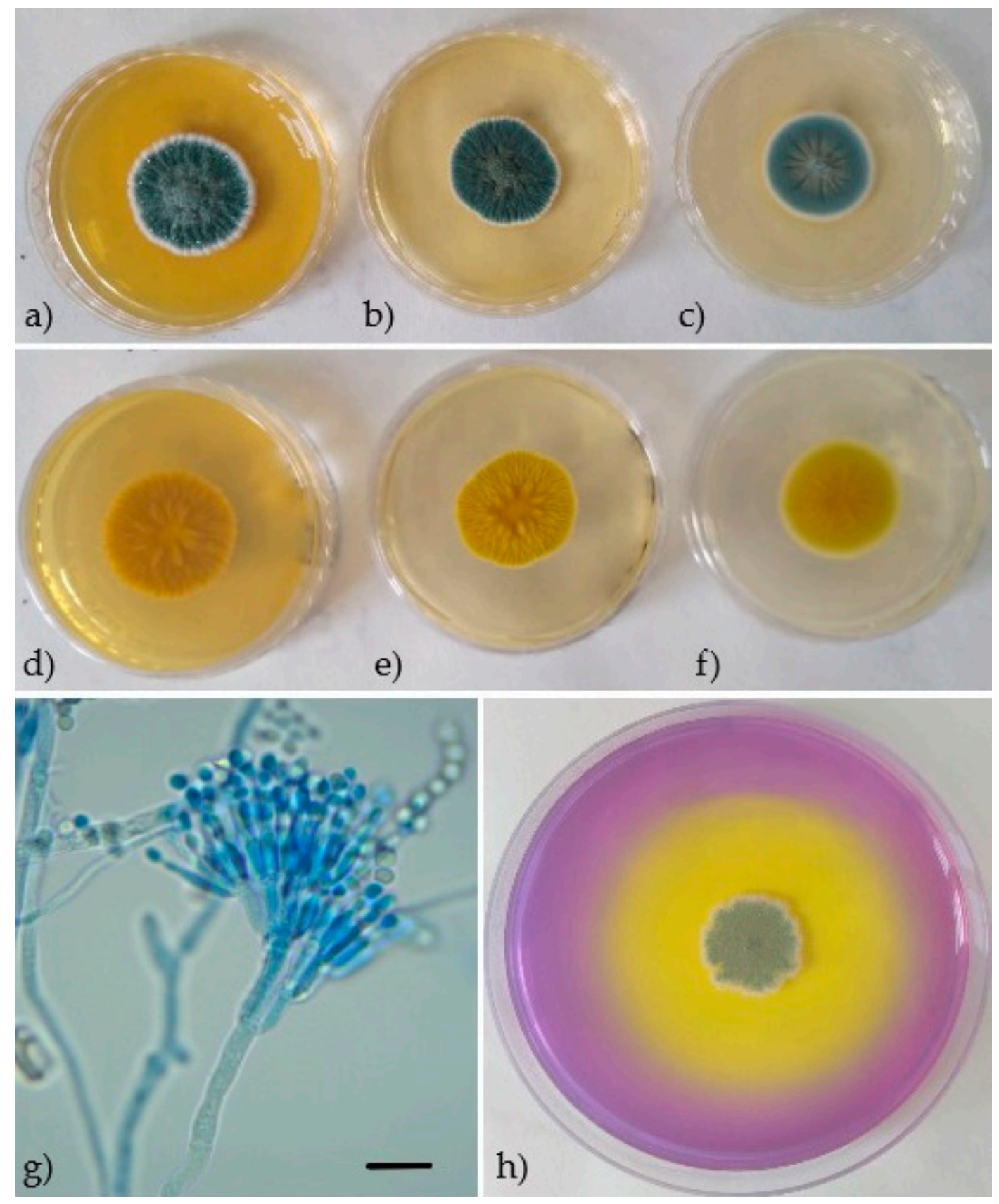

Figure 2. Penicillium commune. Seven-day-old colonies on Malt Extract Agar (MEA) (a) obverse, (d) reverse, Czapek Yeast Autolysate agar (CYA) (b) obverse, (e) reverse, Yeast Extract Sucrose agar (YES) (c) obverse, (f) reverse, (h) Creatine Sucrose Agar (CREA) — strong acid production, $(\mathrm{g})$ conidiophores and conidia. Scale: black bar $=10 \mu \mathrm{m}$.

Identified P. crustosum strains also showed good growth on MEA, CYA, and YES media. The average colony diameters were $(34.10 \pm 4.05) \mathrm{mm}$ for MEA $(34.33 \pm 4.50) \mathrm{mm}$ for CYA and (34.76 \pm 4.90$) \mathrm{mm}$ for YES agar after incubation at $25^{\circ} \mathrm{C}$ for 7 days. Colonies 
on both MEA and CYA were weakly fasciculate to crustose, dull green to grey green with corrugation and thin white edge hem. Reverse colony color on MEA was cream to beige. On CYA, copious clear or brown exudate droplets were present and reverse colony color was cream to yellow brown. Characteristic crustose colonies of grey green color with thin white edge hem and cream to yellow reverse were observed on YES medium. Conidiophores were terverticillate with rough-walled stripe, phialides cylindrical tapering to a distinct collulum. Conidia were smooth-walled, globose to subglobose. Negative Ehrlich reaction was manifested by 13 strains and good acid production was observed in 14 strains (Table 2, Figure 3).
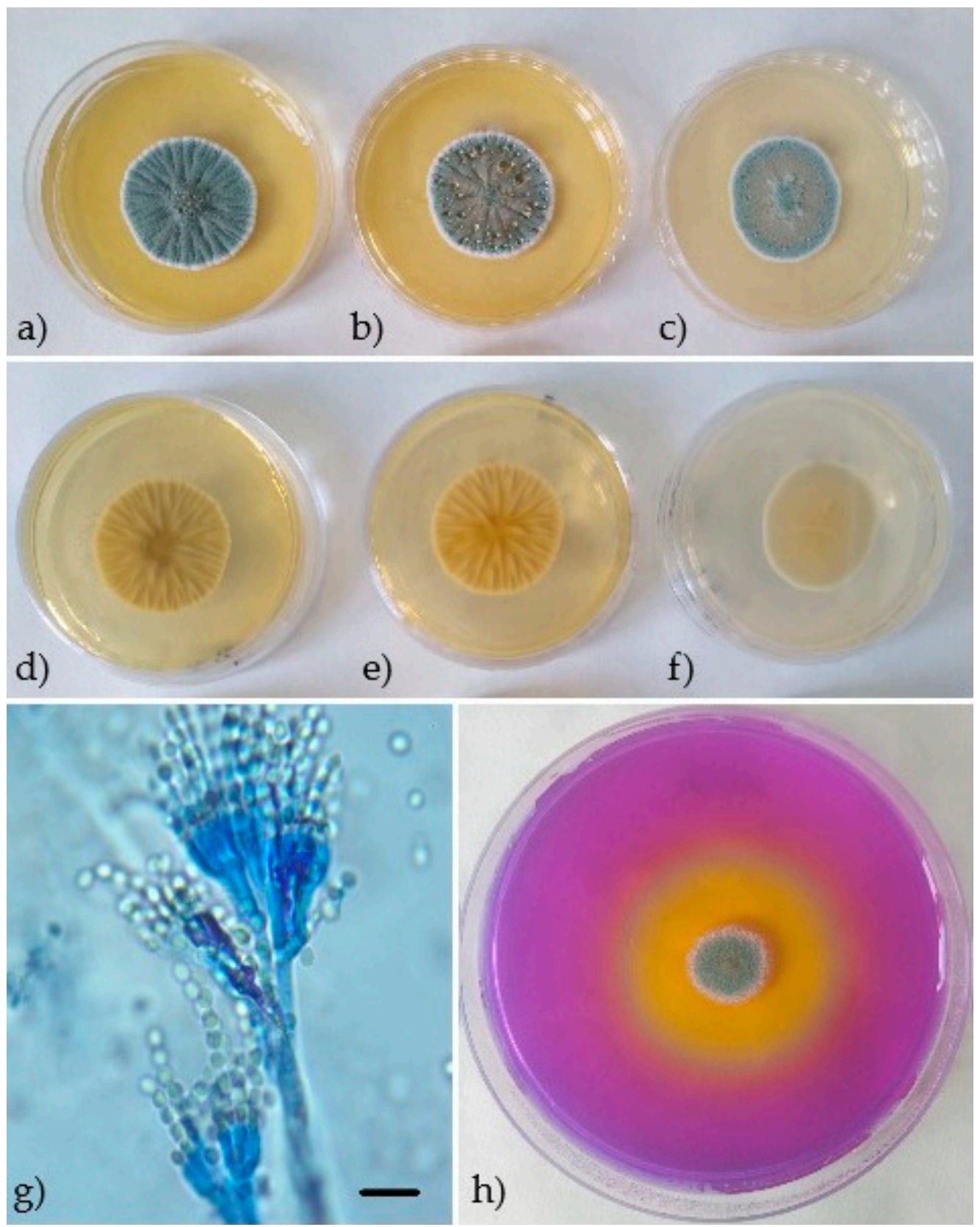

Figure 3. Penicillium crustosum. Seven-day-old colonies on Malt Extract Agar (MEA) (a) obverse, (d) reverse, Czapek Yeast Autolysate agar (CYA) (b) obverse, (e) reverse, Yeast Extract Sucrose agar (YES) (c) obverse, (f) reverse, (h) Creatine Sucrose Agar (CREA)—good acid production, (g) conidiophores and conidia. Scale: black bar $=10 \mu \mathrm{m}$. 


\subsection{PCR-ITS-RFLP Analysis}

The ITS1 and ITS4 primers were used to amplify ITS1-5.8S-ITS2 region of rRNA, which shows low intraspecific polymorphism and high interspecific variability. PCR-ITSRFLP was initially performed with the reference strains, where the ribosomal restriction patterns were assembled. Amplicons of size $650 \mathrm{bp}$ (P. commune and P. crustosum) or $600 \mathrm{bp}$ (P. verrucosum) were digested by seven restriction endonucleases: Bsp1286I, XmaI, HaeIII, HinfI, MseI, SfcI, and Hpy188I. Ribosomal restriction patterns of the tested strains were compared against those of particular reference strains.

Based on these results, three species within the genus Penicillium have been identified: P. verrucosum, P. commune, and P. crustosum (Table 3). Ribosomal restriction patterns of the three species after visualization by ultraviolet (UV) transillumination are presented in Figure 4 .

Table 3. Species-specific identification of Penicillium species based on ribosomal restriction patterns.

\begin{tabular}{|c|c|c|c|c|}
\hline & & \multicolumn{3}{|c|}{ Fungal Species } \\
\hline & & P. verrucosum & P. commune & P. crustosum \\
\hline \multirow{2}{*}{\multicolumn{2}{|c|}{$\begin{array}{l}\text { Number of isolates } \\
\text { PCR amplicons (bp) }\end{array}$}} & 8 & 36 & 19 \\
\hline & & 600 & 650 & 650 \\
\hline \multirow{7}{*}{$\begin{array}{l}\text { Restriction fragments } \\
\qquad(\mathrm{bp})\end{array}$} & Bsp1286I & $41+60+169+263$ & $164+260$ & $169+263$ \\
\hline & $X m a \mathrm{I}$ & $467+128$ & 495 & $497+142$ \\
\hline & HaeIII & $40+54+72+110+260$ & $72+260$ & $54+72+260$ \\
\hline & $\operatorname{HinfI}$ & $112+180+298$ & 275 & 300 \\
\hline & MseI & $201+362$ & $101+353$ & $103+365$ \\
\hline & $S f_{C} \mathrm{I}$ & $110+491$ & $100+464$ & $110+491$ \\
\hline & Hpy188I & $168+400$ & $135+170$ & $53+135+152$ \\
\hline
\end{tabular}

PCR fragments below $40 \mathrm{bp}$ were not displayed.

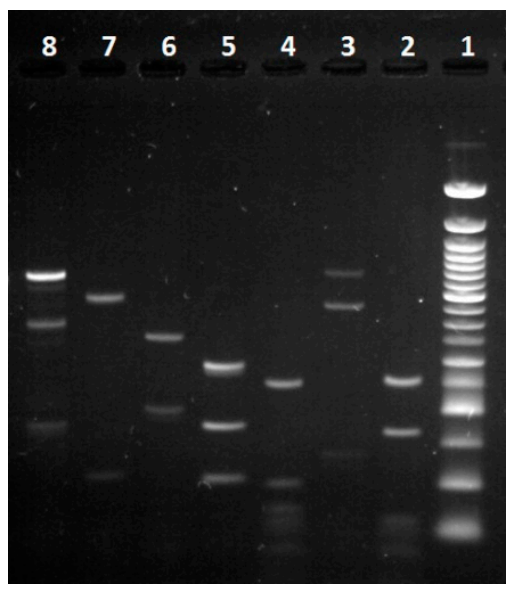

(a)

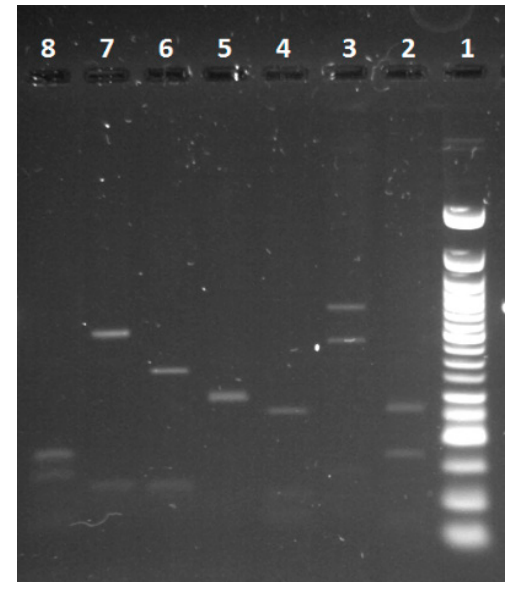

(b)

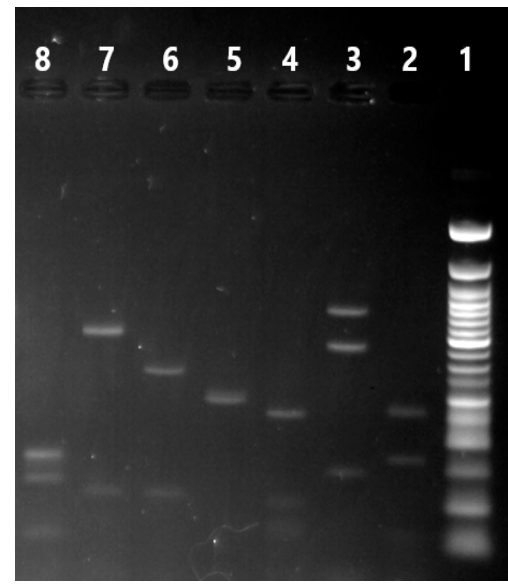

(c)

Figure 4. Restriction patterns presented by the reference strains and Penicillium $(P$.) isolates analyzed: (a) P. verrucosum. Line 1: 50 bp ladder standard; Lines 2 to 8: restriction fragments formed after digestion by endonucleases Bsp1286I, XmaI, HaeIII, HinfI, MseI, SfCI, and Hpy188I; (b) P. commune. Line 1: 50 bp ladder standard; Lines 2 to 8: restriction fragments formed after digestion by endonucleases Bsp1286I, XmaI, HaeIII, HinfI, MseI, SfcI, and Hpy188I; (c) P. crustosum. Line 1: 50 bp ladder standard; Lines 2 to 8: restriction fragments formed after digestion by endonucleases Bsp1286I, XmaI, HaeIII, HinfI, MseI, SfCI, and Hpy188I. 


\subsection{Identification by Conventional PCR}

Penicillium strains identified with the help of PCR-ITS-RFLP were further confirmed by conventional PCR method using the primers designed on the ITS1-5.8S-ITS2 rRNA sequences. The specificity of primer pairs used in conventional PCR was tested with reference strains of seven Penicillium species. The expected sizes of amplicons were about $607 \mathrm{bp}$ for VERF/VERR (P. verrucosum), $464 \mathrm{bp}$ for COMF/COMR (P. commune), and $892 \mathrm{bp}$ for CRUF/CRUR (P. crustosum). In the case of remaining four Penicillium species tested, no PCR products were displayed (Figure 5). Subsequently, Penicillium isolates from table eggs were tested for amplification using the same primer pairs and compared to a particular reference strain. Primers 18S-F/18S-R were used as positive amplification control in this assay (Figure 6).

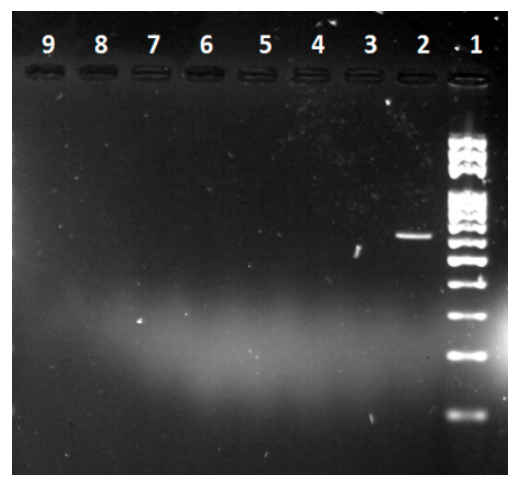

(a)

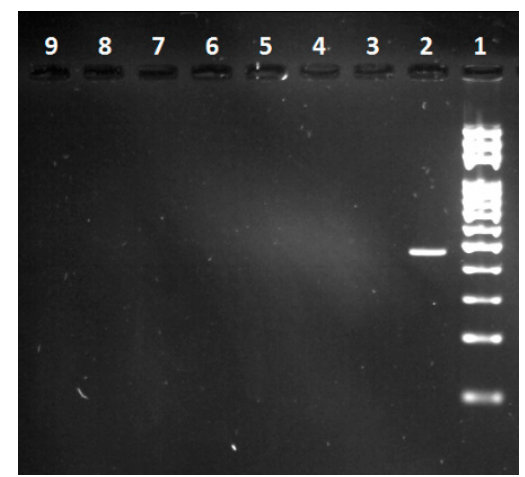

(b)

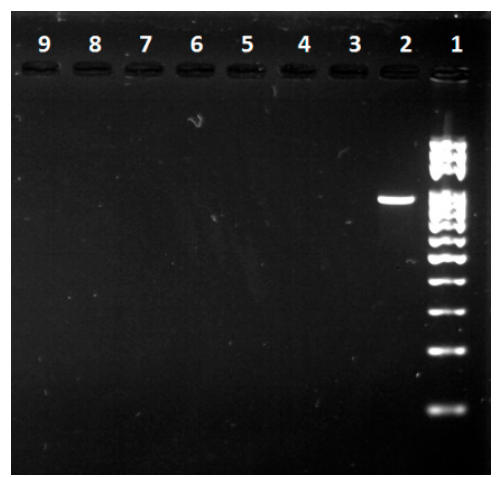

(c)

Figure 5. The specificity of primer pairs used in conventional PCR. (a) DNA amplicons of Penicillium (P.) reference strains using the VERF/VERR primer pair. Line 1: 100 bp ladder standard; Line 2: P. verrucosum (ATCC ${ }^{\circledR} 44407^{\mathrm{TM}}$ ); Line 3: negative control; Line 4 to 9: reference strains P. commune (CCM F-327), P. crustosum (CCM 8322), P. chrysogenum (CCM F-362), P. brevicompactum (CCM 8040), P. glabrum (CCM F-310), P. expansum (CCM F-576); (b) DNA amplicons of Penicillium reference strains using the COMF/COMR primer pair. Line 1: 100 bp ladder standard; Line 2: P. commune (CCM F-327); Line 3: negative control; Line 4 to 9: reference strains P. verrucosum (ATCC ${ }^{\circledR} 44407^{\mathrm{TM}}$ ); P. crustosum (CCM 8322), P. chrysogenum (CCM F-362), P. brevicompactum (CCM 8040), P. glabrum (CCM F-310), P. expansum (CCM F-576); (c) DNA amplicons of Penicillium reference strains using the COMF/COMR primer pair. Line 1: $100 \mathrm{bp}$ ladder standard; Line 2: P. crustosum (CCM 8322); Line 3: negative control; Line 4 to 9: reference strains P. verrucosum (ATCC ${ }^{\circledR} 44407^{\mathrm{TM}}$ ); P. commune (CCM F-327), P. chrysogenum (CCM F-362), P. brevicompactum (CCM 8040), P. glabrum (CCM F-310), P. expansum (CCM F-576).

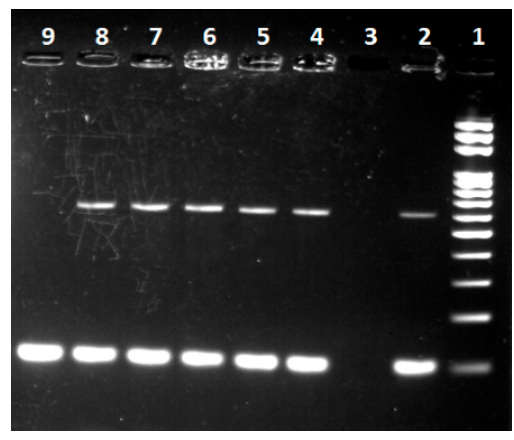

(a)

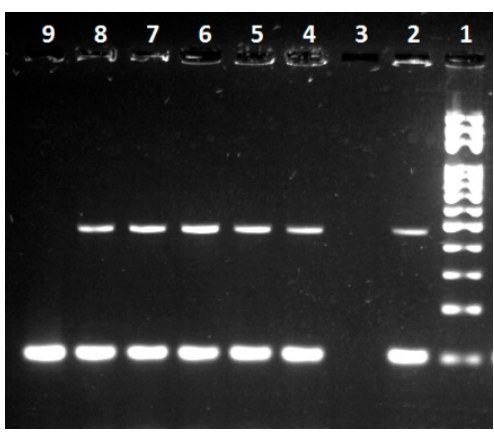

(b)

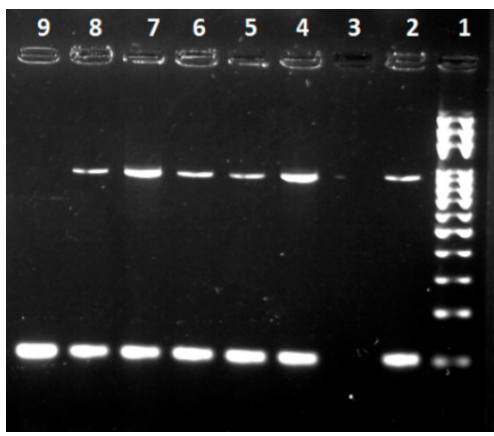

(c)

Figure 6. Electrophoretic analysis of amplicons of Penicillium (P.) isolates from table eggs by conventional PCR. (a) P. verrucosum: Line 1: 100 bp ladder standard; Line 2: P. verrucosum (ATCC ${ }^{\circledR} 44407^{\mathrm{TM}}$ ); Line 3: negative control; Lines 4 to 8: isolates of P. verrucosum (607 bp); Line 9: $18 \mathrm{~S}$ rRNA internal control (99 bp); (b) P. commune: Line 1: $100 \mathrm{bp}$ ladder standard; Line 2: P. commune (CCM F-327); Line 3: negative control; Lines 4 to 8: isolates of P. commune (464 bp); Line 9: $18 \mathrm{~S}$ rRNA internal control (99 bp); (c) P. crustosum: Line 1: 100 bp ladder standard; Line 2: P. crustosum (CCM 8322); Line 3: negative comtrol; Lines 4 to 8: isolates of P. crustosum (892 bp); Line 9: $18 \mathrm{~S}$ rRNA internal control (99 bp). 


\subsection{Comparison of Results Obtained by Three Identification Methods}

Initial identification of Penicillium isolates was based on evaluation of both macroscopic and microscopic features. After that, more accurate identification was performed using two molecular methods.

The results of this study showed the lowest coincidence in the group of $P$. verrucosum isolates, were only eight strains, out of 12 strains identified morphologically, were confirmed by molecular methods. Among P. commune isolates, 42 out of 48 strains previously identified by phenotypic evaluation, were subsequently confirmed by both PCR methods. The most accurate identification was obtained for P. crustosum, where 21 isolates were identified morphologically and 19 isolates using both molecular methods.

\section{Discussion}

Accurate identification is the basis for all aspects of the diagnosis and epidemiology, whether it is pathology, medical sciences, environmental studies, or biological control. Early identification of the pathogen is crucial for the implementation of corrective actions and control measures. Penicillium spp. are ubiquitous microscopic filamentous fungi that have been isolated from widespread substrates. In this study, microscopic filamentous fungi of Penicillium spp. were isolated from the surface of chicken eggshells. Table eggs are very susceptible to fungal contamination under unsuitable storage conditions, such as increased humidity and absence of air circulation [30]. Fungal contamination of chicken eggs has been described in several studies [31-33]. Regecová et al. [26] reported the occurrence of microscopic filamentous fungi of Penicillium spp., Aspergillus spp., Cladosporium spp., and Alternaria alternate group in chicken eggs. Similar results were obtained by Rajmani et al. [34]. In the study of Neamatallah et al. [35], 38\% of the eggs examined were contaminated with spores of potentially toxinogenic Penicillium, Aspergillus, and Fusarium species. According to Tomczyk et al. [36], fungi belonging to Alternaria, Penicillium, and Chaetomium spp. are the most common contaminants of the eggshell surface.

Food contamination by Penicillium spp. is far common in all industrial food sectors and leads to economic losses and potential risk for public health. In addition, identification of Penicillium species may be challenging in conventional cultivation methods. These are based on the isolation of microorganisms followed by morphological and biochemical identifications, the results of which often lead to identification problems.

For long time, $P$. commune was considered to be a fungal pathogen frequently associated with cheeses [37]. Current studies prove that P. commune is a cosmopolitan species with a high saprophytic ability to colonize different types of substrates [38].

P. crustosum is an important and panglobal contaminant of lipid- and protein-rich foods and feeds. This species is extremely consistent in its phenotypic properties, including morphology, physiology, and the production of secondary metabolites. However, some food isolates may differ from the others by weak growth on Creatine agar medium [14].

In this study, phenotypic identification was performed according to the identification key established by Frisvad and Samson [11]. As reported by the authors, P. crustosum and $P$. verrucosum do not produce cyclopiazonic acid or other alkaloids, i.e., the Ehrlich reaction should be negative. However, testing of Penicillium isolates in this study has also provided positive (yellow) Ehrlich reaction in some of P. crustosum and P. verrucosum strains. Similar finding were also presented by Bragulat et al. [39]. Along with strong violet reaction reported for $P$. commune strains $[11,40]$, purple or negative reactions have also been observed in this study. As to the creatine test, weak growth of $P$. verrucosum with no acid production on CREA was expected [11]. In this study, five P. verrucosum isolates showed good growth on CREA and strong acid production was confirmed in four isolates. In contrary, very good growth and very good acid production on CREA were reported for both P. crustosum and P. commune strains [11]. Nevertheless, weak growth was observed in nine strains of $P$. commune and seven strains of $P$. crustosum. Weak acid production was confirmed in eleven P. commune isolates and seven P. crustosum isolates did not even produce any acid at all. Based on typical morphological and phenotypic characteristics, 
Penicillium isolates were identified as P. verrucosum, P. commune, or P. crustosum. Some discrepancies revealed in this study could be explained by the fact that the production of secondary metabolites may not be expressed in all strains within a particular species [41]. To confirm the results of phenotypic identification, the isolates were further subjected to species-specific molecular identification.

Cultivation of molds is time-consuming, labor-intensive, non-quantitative, and susceptible to contamination and inaccuracies in classification. There is therefore a general need to design new, fast, highly specific, and reliable identification methods. In this study, two molecular methods were used for final identification of Penicillium species isolated from chicken eggs. As no conventional PCR assay has been available so far, three species-specific primer pairs were designed and introduced in this study to distinguish closely related species of $P$. verrucosum, P. commune, and P. crustosum. The PCR-ITS-RFLP assay was used to verify specificity and reliability of the results obtained by conventional PCR assay. Among the regions of the ribosomal cistron, the ITS region has the highest probability of successful identification for the broadest range of fungi, with the most clearly defined barcode gap between inter- and intraspecific variation [42]. The PCR-ITS-RFLP assay has high reproducibility and low cost $[43,44]$. Due to technical and analytical straightforwardness, it is currently considered as one of the leading fingerprinting methods [45]. In this study, different sizes of DNA restriction fragments allowed to identify all the three Penicillium species (P. verrucosum, P. commune, and P. crustosum). Diguţă et al. [28] proclaimed, that the combination of nine endonucleases (SduI, HinfI, MseI, BfmI, MaeII, Cfr9I, Hpy188I, and PspGI) is sufficient for complete species discrimination. The identification of microscopic filamentous fungi by PCR-ITS-RFLP has been described in many studies [46-55]. The main advantage of this method is that no special equipment is required and the method can be used to identify a wide range of different microorganisms without the need to change the analytical procedure. Thus, the suitability of PCR-ITS-RFLP method for identification of microscopic filamentous fungi has also been confirmed in other studies [12,17,56-58].

Real-time PCR assays with DNA probes were also successfully used to identify P. verrucosum [59], P. commune [60], and P. crustosum [18]. Currently, more recent and effective methods are available for mold species identification. Among them, proteomic assays allow location-specific analysis, as well as the study of post-translational modifications (e.g., phosphorylation and glycosylation), which might impact on signal transduction in eukaryotic systems, such as fungi [61]. Metagenomic analysis can be extensive but requires more complex bioinformatic interpretation and the protocols [62].

In this study, conventional PCR method was designed and compared with both classical morphological identification assay and PCR-ITS-RFLP analysis in an attempt to reduce costs and simplify routine identification procedure of the three Penicillium species. Based on the results obtained it can be concluded that the traditional PCR assay is rapid and highly specific and provides an advantageous alternative to current methods significantly facilitating identification of undesirable penicillia contaminating food. As demonstrated in this study, if the results of morphological identification are not confirmed by molecular methods, the absence of key metabolic features may lead to mold species misidentification.

Both PCR methods used in this study demonstrated the ability to differentiate three Penicillium species at a good level. The evaluation could be probably more challenging when large numbers of samples need to be analyzed using PCR-ITS-RFLP. Considering the time and financial costs of both methods, the newly designed conventional PCR seems to be more advantageous.

Author Contributions: Conceptualization, P.J.; methodology, P.J. and I.R.; software, I.R. and S.D.; formal analysis, M.P.; investigation and data curation, S.D., P.J. and I.R.; writing-original draft preparation, S.D.; writing-review and editing, M.P.; supervision, M.P. and P.J.; project administration and funding acquisition, P.J. All authors have read and agreed to the published version of the manuscript. 
Funding: This work was supported by Scientific Grant Agency of the Ministry of Education, Science, Research and Sport of the Slovak Republic and the Slovak Academy of Sciences (VEGA 1/0705/16).

Institutional Review Board Statement: Not applicable.

Informed Consent Statement: Not applicable.

Data Availability Statement: The data presented in this study are available on request from the corresponding author.

Conflicts of Interest: The authors declare no conflict of interest.

\section{References}

1. Visagie, C.M.; Houbraken, J.; Frisvad, J.C.; Hong, S.-B.; Klaassen, C.H.W.; Perrone, G.; Seifert, K.A.; Varga, J.; Yaguchi, T.; Samson, R.A. Identification and nomenclature of the genus Penicillium. Stud. Mycol. 2014, 78, 343-371. [CrossRef] [PubMed]

2. Samson, R.A.; Houbraken, J.; Thrane, U.; Frisvad, J.C.; Andersen, B. Food and Indoor Fungi, 2nd ed.; CBS Laboratory Manual Series; CBS KNAW Biodiversity Centre: Utrecht, The Netherlands, 2010; Volume 2, p. 390. ISBN 978-90-70351-82-3.

3. Storey, E.; Dangman, K.H.; Schenck, P.; DeBernardo, R.L.; Yang, C.S.; Bracker, A.; Hodgson, M.J. Guidance for Clinicians on the Recognition and Management of Health Effects Related to Mold Exposure and Moisture Indoors; University of Connecticut Health Center: Farmington, CT, USA, 2004; p. 17.

4. Rundberget, T.; Skaar, I.; Flåøyen, A. The presence of Penicillium and Penicillium mycotoxins in food wastes. Int. J. Food Microbiol. 2004, 90, 181-188. [CrossRef]

5. Mansour, A.F.A.; Zayed, A.F.; Basha, O.A.A. Contamination of the shell and internal content of table eggs with some pathogens during different storage periods. Assiut Vet. Med. J. 2015, 61, 8-15.

6. Commission Regulation (EC) No. 589/2008 of 23 June 2008 Laying Down Detailed Rules for Implementing Council Regulation (EC) No. 1234/2007 as Regards Marketing Standards for Eggs. Available online: https:/ / eur-lex.europa.eu/LexUriServ/ LexUriServ.do?uri=OJ:L:2008:163:0006:0023:EN:PDF (accessed on 20 October 2020).

7. Leggieri, M.C.; Pietri, A.; Battilani, P. Modelling fungal growth, mycotoxin production and release in Grana cheese. Microorganisms 2020, 8, 69. [CrossRef] [PubMed]

8. Lund, F.; Nielsen, A.B.; Skouboe, P. Distribution of Penicillium commune isolates in cheese dairies mapped using secondary metabolite profiles, morphotypes, RAPD and AFLP fingerprinting. Food Microbiol. 2003, 20, 20725-20734. [CrossRef]

9. Kure, C.F.; Abeln, E.C.A.; Holst-Jensen, A.; Skaar, I. Differentiation of Penicillium commune and Penicillium palitans isolates from cheese and indoor environments of cheese factories using M13 fingerprinting. Food Microbiol. 2002, 19, 151-157. [CrossRef]

10. Houbraken, J.; Visagie, C.M.; Meijer, M.; Frisvad, J.C.; Busby, P.E.; Pitt, J.I.; Seifert, K.A.; Louis-Seize, G.; Demirel, R.; Yilmaz, N.; et al. A taxonomic and phylogenetic revision of Penicillium section Aspergilloides. Stud. Mycol. 2014, 78, 373-451. [CrossRef]

11. Frisvad, J.C.; Samson, R.A. Polyphasic taxonomy of Penicillium subgenus Penicillium. A guide to identification of food and air-borne terverticillate Penicillia and their mycotoxins. Stud. Mycol. 2004, 49, 1-174.

12. Toju, H.; Tanabe, A.S.; Yamamoto, S.; Sato, H. High-coverage ITS primers for the DNA-based identification of ascomycetes and basidiomycetes in environmental samples. PLoS ONE 2012, 7, e40863. [CrossRef]

13. Koffi, Y.F.; Diguta, C.; Alloue-Boraud, M.; Ban Koffi, L.; Dje, M.; Gherghina, E.; Matei, F. PCR-ITS-RFLP identification of pineapple spoilage fungi. Rom. Biotechnol. Lett. 2019, 24, 418-424. [CrossRef]

14. Sonjak, S.; Frisvad, J.C.; Gunde-Cimerman, N. Genetic Variation among Penicillium crustosum isolates from arctic and other ecological niches. Microb. Ecol. 2007, 54, 298-305. [CrossRef] [PubMed]

15. Chen, R.S.; Tsay, J.G.; Huang, Y.F.; Chiou, R.Y. Polymerase chain reaction-mediated characterization of molds belonging to the Aspergillus flavus group and detection of Aspergillus parasiticus in peanut kernels by multiplex polymerase chain reaction. J. Food Prot. 2002, 65, 840-844. [CrossRef] [PubMed]

16. Apaliya, M.T.; Zhang, H.; Zheng, X.; Yang, Q.; Mahunu, G.K.; Kwaw, E. Exogenous trehalose enhanced the biocontrol efficacy of Hanseniaspora uvarum against grape berry rots caused by Aspergillus tubingensis and Penicillium commune. J. Sci. Food Agric. 2018, 98, 4665-4672. [CrossRef] [PubMed]

17. Dhungana, B.; Ali, S.; Byamukama, E.; Krishnan, P.; Caffe-Treml, M. Incidence of Penicillium verrucosum in grain samples from oat varieties commonly grown in South Dakota. J. Food Prot. 2018, 81, 898-902. [CrossRef]

18. Gonda, M.; Rufo, C.; Cecchetto, G.; Vero, S. Evaluation of different hurdles on Penicillium crustosum growth in sponge cakes by means of a specific real time PCR. J. Food Sci. Technol. 2019, 56, 2195-2204. [CrossRef]

19. Al-Anati, L.; Petzinger, E. Immunotoxic activity of ochratoxin A. J. Vet. Pharmacol. Ther. 2006, 29, 79-90. [CrossRef]

20. Frisvad, J.C.; Smedsgaard, J.; Larsen, T.O.; Samson, R.A. Mycotoxins, drugs and other extrolites produced by species in Penicillium subgenus Penicillium. Stud. Mycol. 2004, 49, 201-241.

21. Moldes-Anaya, A.; Rundberget, T.; Fæste, C.K.; Eriksen, G.S.; Bernhoft, A. Neurotoxicity of Penicillium crustosum secondary metabolites: Tremorgenic activity of orally administered penitrem A and thomitrem A and E in mice. Toxicon 2012, 60, 1428-1435. [CrossRef]

22. Vinokurova, N.G.; Ozerskaya, S.M.; Baskunov, B.P.; Arinbasarov, M.U. The Penicillium commune Thom and Penicillium clavigerum Demelius fungi-Fumigaclavines A and B producers. Mikrobiologiia 2003, 72, 180-182. [CrossRef] 
23. Wagener, R.E.; Davis, N.D.; Diener, U.L. Penitrem A and Roquefortine Production by Penicillium commune. Appl. Environ. Microbiol. 1980, 39, 882-887. [CrossRef]

24. STN ISO 21527-1. Microbiology of Food and Animal Feeding Stuffs. Horizontal Method for the Enumeration of Yeasts and Molds. Part 1: Colony Count Technique in Products with Water Activity Greater than 0.95; ISO 21527-1:2008; Slovak Standards Institute: Bratislava, Slovak Republic, 2010.

25. STN ISO 21527-2. Microbiology of Food and Animal Feeding Stuffs. Horizontal Method for the Enumeration of Yeasts and Molds. Part 2: Colony Count Technique in Products with Water Activity less than or Equal to 0.95; ISO 21527-2:2008; Slovak Standards Institute: Bratislava, Slovak Republic, 2010.

26. Regecová, I.; Pipová, M.; Jevinová, P.; Demjanová, S.; Semjon, B. Quality and mycobiota composition of stored eggs. Ital. J. Food Sci. 2020, 32, 540-561. [CrossRef]

27. White, T.J.; Bruns, T.D.; Lee, S.B.; Taylor, J.W. Amplification and direct sequencing of fungal ribosomal RNA genes for phylogenetics. In PCR Protocols: A Guide to Methods and Applications; Innis, M.A., Gelfand, D.H., Sninsky, J.J., White, T.J., Eds.; Academic Press: New York, NY, USA, 1990; pp. 315-322. ISBN -978-0-12372180-8. [CrossRef]

28. Diguţă, C.F.; Vincent, B.; Guilloux-Benatier, M.; Alexandre, H.; Rousseaux, S. PCR ITS-RFLP: A useful method for identifying filamentous fungi isolates on grapes. Food Microbiol. 2011, 28, 1145-1154. [CrossRef] [PubMed]

29. López-Andreo, M.; Lugo, L.; Garrido-Pertierra, A.; Prieto, M.I.; Puyet, A. Identification and quantitation of species in complex DNA mixtures by real-time polymerase chain reaction. Anal. Biochem. 2005, 339, 73-82. [CrossRef] [PubMed]

30. Al-Obaidi, F.A.; Al-Shadeedi, S.M.J.; Al-Dalawi, R.H. Quality, chemical and microbial characteristics of table eggs at retail stores in Baghdad. Inter. J. Poultry. Sci. 2011, 10, 381-385. [CrossRef]

31. Perez-Nadales, E.; Nogueira, M.D.; Baldwin, C.; Castanheira, S.E.; Ghalid, M.; Grund, E.; Lengeler, K.; Marchegiani, E.; Mehrotra, P.V.; Moretti, M.; et al. Fungal model systems and the elucidation of pathogenicity determinants. Fungal Genet. Biol. 2014, 70, 42-67. [CrossRef] [PubMed]

32. Hassan, Z.U.; Ahmad, S. Transfer of mycotoxin residues in hen's egg, their interaction and mechanism. In Handbook of Eggs in Human Function. Human Health Handbooks; Watson, R.R., De Meester, F., Eds.; Wageningen Academic Publishers: Wageningen, The Netherlands, 2015; Volume 9, pp. 365-386. ISBN 978-90-8686-254-2. [CrossRef]

33. Rodríguez, A.; Rodríguez, M.; Anreade, M.J.; Córdoba, J.J. Detection of filamentous fungi in foods. Curr. Opin. Food. Sci. 2015, 5, 36-42. [CrossRef]

34. Rajmani, R.S.; Singh, A.P.; Singh, P.K.; Doley, J.; Verma, S.P. Fungal contamination in eggs. J. Vet. Pub. Health 2011,9 , 59-61. [CrossRef]

35. Neamatallah, A.A.; El-Leboudy, A.; Amer, A.A.; El-Shenawy, N.M. Biosafety against fungal contamination of hen's eggs and mycotoxins producing species. JKAU Met. Environ. Arid Land Agric. Sci. 2009, 20, 63-73. [CrossRef]

36. Tomczyk, Ł.; Stepień, Ł.; Urbaniak, M.; Szablewski, T.; Cegielska-Radziejewska, R.; Stuper-Szablewska, K. Characterisation of the mycobiota on the shell surface of table eggs acquired from different egg-laying hen breeding systems. Toxins 2018, 10, 293. [CrossRef]

37. Ramos-Pereiraa, J.; Marezeb, J.; Patrinoua, E.; Santosa, J.A.; Lopez-Diaza, T.-M. Polyphasic identification of Penicillium spp. isolated from Spanish semi-hard ripened cheeses. Food Microbiol. 2019, 84, 103253:1-103253:8. [CrossRef]

38. Rodríguez, R.D.; Heredia, G.; Siles, J.A.; Jurado, M.; Saparrat, M.C.N.; García-Romera, I.; Sampedro, I. Enhancing laccase production by white-rot fungus Funalia floccosa LPSC 232 in co-culture with Penicillium commune GHAIE86. Folia Microbiol. 2019, 64, 91-99. [CrossRef] [PubMed]

39. Bragulat, M.R.; Martínez, E.; Castellá, G.; Cabañes, F.J. Ochratoxin A and citrinin producing species of the genus Penicillium from feedstuffs. Int. J. Food Microbiol. 2008, 126, 43-48. [CrossRef] [PubMed]

40. Zhelifonova, V.P.; Antipova, T.V.; Kozlovskii, A.G. Effect of potassium sorbate, sodium benzoate, and sodium nitrite on biosynthesis of cyclopiazonic and mycophenolic acids and citrinin by fungi of the Penicillium genus. Appl. Biochem. Microbiol. 2017, 53, 711-714. [CrossRef]

41. Pitt, J.I.; Hocking, A.D. Fungi and Food Spoilage, 3rd ed.; Springer Science \& Business Media: New York, NY, USA, 2009; ISBN 978-0-387-92207-2. [CrossRef]

42. Schoch, C.L.; Seifert, K.A.; Huhndorf, S.; Robert, V.; Spouge, J.L.; Levesque, C.A.; Chen, W. Fungal Barcoding Consortium. Nuclear ribosomal internal transcribed spacer (ITS) region as a universal DNA barcode marker for Fungi. PNAS 2012, 109, 6241-6246. [CrossRef] [PubMed]

43. Thies, J.E. Soil microbial community analysis using terminal restriction fragment length polymorphisms. SSSA J. 2007, 71, 579-591. [CrossRef]

44. Cao, Y.; Van De Werfhorst, L.C.; Dubinsky, E.A.; Badgley, B.D.; Sadowsky, M.J.; Andersen, G.L.; Griffith, J.F.; Holden, P.A. Evaluation of molecular community analysis methods for discerning fecal sources and human waste. Water Res. 2013, 47, 6862-6872. [CrossRef]

45. Schütte, U.M.E.; Abdo, Z.; Bent, S.J.; Shyu, C.; Williams, C.J.; Pierson, J.D.; Forney, L.J. Advances in the use of terminal restriction fragment length polymorphism (T-RFLP) analysis of $16 \mathrm{~S}$ rRNA genes to characterize microbial communities. Appl. Microbiol. Biotechnol. 2008, 80, 365-380. [CrossRef] [PubMed]

46. Khalil, M.I. Identification of Cladosporium sp. Fungi by in- silico RFLP-PCR. Baghdad Sci. J. 2020, 17, 220-226. [CrossRef] 
47. Leite, L.N.; Lelis, F.J.N.; de Sousa Xavier, M.A.; dos Santos, J.; Cardoso, L.; Barbosa, F.S.; dos Santos, R.F.; Dias, S.A.M.; de Oliveira Xavier, A.R.E. Molecular identification and characterization of filamentous fungi and yeasts isolated in a pharmaceutical industry environment. J. Appl. Pharm. Sci. 2020, 10, 27-36. [CrossRef]

48. Szekely, J.; Chelae, S.; Ingviya, N.; Rukchang, W.; Auepemkiate, S.; Aiempanakit, K. Universal Multiplex Polymerase Chain Reaction-Restriction Fragment Length Polymorphism (UMPCR-RFLP) for rapid detection and species identification of fungal and mycobacterial pathogens. Walailak J. Sci. Tech. 2020, 17, 1113-1125. [CrossRef]

49. Kordalewska, M.; Kalita, J.; Bakuła, Z.; Brillowska-Dąbrowska, A.; Jagielski, T. PCR-RFLP assays for species-specific identification of fungi belonging to Scopulariopsis and related genera. Med. Mycol. 2019, 57, 643-648. [CrossRef] [PubMed]

50. Worasilchai, N.; Chaumpluk, P.; Chakrabarti, A.; Chindamporn, A. Differential diagnosis for pythiosis using thermophilic helicase DNA amplification and restriction fragment length polymorphism (tHDA-RFLP). Med. Mycol. 2018, 56, 216-224. [CrossRef] [PubMed]

51. Atoui, A.; El Khoury, A. PCR-RFLP for Aspergillus species. In Mycotoxigenic Fungi. Methods in Molecular Biology; Moretti, A., Susca, A., Eds.; Humana Press: New York, NY, USA, 2017; Volume 1542, ISBN 978-1-4939-6707-0. [CrossRef]

52. Kim, J.S.; Kang, N.J.; Kwak, Y.S.; Lee, C. Investigation of Genetic Diversity of Fusarium oxysporum f. sp. fragariae using PCR-RFLP. Plant. Pathol. J. 2017, 33, 140-147. [CrossRef] [PubMed]

53. Rousseaux, S.; Guilloux-Bénatier, M. PCR ITS-RFLP for Penicillium species and other genera. In Mycotoxigenic Fungi. Methods in Molecular Biology; Moretti, A., Susca, A., Eds.; Humana Press: New York, NY, USA, 2017; Volume 1542, ISBN 978-1-4939-6707-0. [CrossRef]

54. Srivastava, S.; Gupta, P.S.; Lal, S.; Sinha, O.K. Rapid identification of endophytic fungi of sugarcan (saccharum spp. hybrid) using PCR-RFLP of rDNA. J. Environ. Biol. 2017, 38, 21-26. [CrossRef]

55. Grudzinska-Sterno, M.; Yuen, J.; Stenlid, J.; Djurle, A. Fungal communities in organically grown winter wheat affected by plant organ and development stage. Eur. J. Plant. Pathol. 2016, 146, 401-417. [CrossRef]

56. Diguță, C.F.; Toma, R.C.; Cornea, C.P.; Matei, F. Molecular detection of black Aspergillus and Penicillium species from Dealu Mare vineyard. Sci. Pap. Ser. B Hortic. 2018, 62, 305-310.

57. De Sousa, D.R.T.; da Silva Santos, C.S.; Wanke, B.; da Silva, R.M., Jr.; dos Santos, M.C.; Cruz, K.S.; Monte, R.L.; Nocker, A.; de Souza, J.V.B. PCR-RFLP as a useful tool for diagnosis of invasive mycoses in a healthcare facility in the North of Brazil. Electron. J. Biotechnol. 2015, 18, 231-235. [CrossRef]

58. Ziaee, A.; Zia, M.; Bayat, M.; Hashemi, J. Molecular Identification of Mucor and Lichtheimia species in pure cultures of Zygomycetes. Jundishapur J. Microbiol. 2016, 9, e35237:1-e35237:8. [CrossRef]

59. Vegi, A.; Wolf-Hall, C.E. Multiplex real-time PCR method for detection and quantification of mycotoxigenic fungi belonging to three different genera. J. Food Sci. 2013, 78, M70-M76. [CrossRef]

60. Rodríguez, A.; Luque, M.I.; Andrade, M.J.; Rodríguez, M.; Asensio, M.A.; Córdoba, J.J. Development of real-time PCR methods to quantify patulin-producing molds in food products. Food Microbiol. 2011, 28, 1190-1199. [CrossRef]

61. Pandey, A.; Mann, M. Proteomics to study genes and genomes. Nature 2000, 405, 837-846. [CrossRef] [PubMed]

62. Balint, M.; Bahram, M.; Murat Eren, A.; Faust, K.; Fuhrman, J.A.; Orn Lindahl, B.; O'Hara, R.B.; Opik, M.; Sogin, M.L.; Unterseher, M.; et al. Millions of reads, thousands of taxa: Microbial community structure and associations analyzed via marker genes FEMS microbiology reviews advance access. FEMS Microbiol. Rev. 2016, 40, 686-700. [CrossRef] [PubMed] 